\author{
장출혈성대장균 O157:H7 유래 재조합 Intimin의 발현과 \\ 그의 면역반응 효과 \\ 김도균 · 이상래 · 김정우 \\ 단국대학교 동물자원학과
}

\title{
Expression of Recombinant Intimin of Escherichia coli O157:H7 and its Effect of Immune Response
}

\author{
D. G. Kim, S. R. Lee and J. W. Kim \\ Department of Animal Science and Resources, Dankook University
}

\begin{abstract}
Intimin, the product of eae gene in EHEC O157:H7, is required for intimate adherence. In this study, the C-terminal region(281 amino acids) of the EHEC O157:H7 intimin were expressed as a protein fusion with (His) 6 , which was used to raise antiserum in rabbits. The antiserum reacted in western blot with a $94 \mathrm{kDa}$ outer membrane protein of EHEC O157:H7. It was observed that the antibody titers both in egg yolk and serum appeared in $2 \sim$ weeks after immunization with fusion protein. At the time of 8 weeks, the titre of egg yolk was found to be higher than that of sera. According to the results of neutralization test, chicken egg-yolk antibody(IgY) against the recombinant intimin strongly reacted to EHEC O157:H7. We conclude that a truncated recombinant intimin could be used as an immunogen to elicit antibody(IgY) against O157:H7.
\end{abstract}

(Key words : EHEC O157:H7, Recombinant intimin, IgY)

$$
\mathrm{I} \text { 서 론 }
$$

Escherichia coli O157:H7은 장관출혈성대장 균(Enterohemorrhagic Escherichia coli; EHEC) 으로써 사람에서 출혈성대장염(hemorrhagic colitis) 및 용혈성요독증후군(hemolytic uremic syndrome) 등을 유발하며, vero 세포주에 독 성을 나타내는 독소인 verotoxin을 생성하는 대장균(verotoxigenic E. coli; VTEC)으로도 잘 알려져 있다(Konowalchuk 등, 1977;Karmaili 등, 1989). 미국뿐만 아니라 캐나다 등 세계 여러 선 진국에서 발생현황이 보고되고 있으며, 국내에 서는 정 등(1996)이 최초로 O157:H7 균을 환자 로부터 분리하여 보고하였고 또한 $\mathrm{Kim}$ 등(1998) 도 1990년에서 1996년 사이에 환자에서 O157:
$\mathrm{H7}$ 균이 분리되었다고 보고된 바 있다. 최근까 지도 우리나라의 수입육우의 최대 공급국인 미 국의 주요 4대 육우 생산 주에서 여전히 소의 분변 등에서 $\mathrm{O} 157: \mathrm{H7}$ 균이 분리되고 있다는 보 고가 있기 때문에(Sargeant 등, 2003), VTEC O157:H7의 식육에의 오염으로 인한 인체감염의 위험요소로 작용하고 있다.

VTEC 0157:H7의 생화학적 성상은 일반대장 균과 대부분 유사하나 sorbitol을 분해하지 못하 고 MUG(4-methylumbeliferyl- $\beta$-D-glucuronide) 배 지에서 음성반응이 나타나는 차이점이 있어서 이를 이용한 선택배지의 개발에 활발한 연구가 진행되어 왔고(Kleanthous 등, 1988), 현재는 다양 한 종류의 선택배지가 시판중이다. VTEC가 분비 하는 verotoxin(VT)은 3종류 즉, VT1, VT2 및 VTE

Corresponding author : Jung-Woo Kim. Department of Animal Science and Resources, Dankook University, Cheonan, Korea, 330-714. Tel : 041-550-3651, Fax : 041-555-8652, E-mail : kijuw@dankook.ac.kr 
로 알려져 있다(Konowalchuk 등, 1978). O'Brien 등(1984)은 Shigella dysenteriae type I의 독소 (shiga toxin)에 대한 항혈청에 중화되는 $\mathrm{VT}$ 를 shiga-like toxin I이라 명하였고, Marques 등(1986) 은 shiga toxin의 항혈청에 중화되지 않는 VT를 shiga-like toxin ㅍ 고공여영하였다. VT의 구조는 하나의 A subunit $(32 \mathrm{kDa})$ 와 다섯 개의 B subunit (각 7.7kDa)로 이루어져 있다(O’Brien과 LaVeck, 1983). A, B subunit은 숙주세포의 ribosome에 결 합하는 elongation-factor-1 의존성 aminoacyl-tRNA 을 억제하여 궁극적으로 단백질 합성을 저해하 는 것으로 알려져 있다(Endo 등, 1988).

EHEC O157:H7은 실험동물의 회장, 맹장, 결 장에 군락을 형성한다고 보고되었다(Tzipori 등, 1987). VTEC O157:H7의 발병기전은, VTEC가 장관에 군락을 형성한 다음, 장관 내에서 $\mathrm{VT}$ 를 생산하고 생산된 VT가 장관으로부터 흡수 된 후, 호발장기의 혈관내피세포에 부착하여 손상을 줌으로서 부종, 출혈 및 혈전증을 유발 하는 것으로 알려져 있다(Gyles와 Thoen, 1993; Tesh과 O’Brien, 1992). 따라서 VTEC에 의한 질병발생을 예방하기 위해서는 VTEC가 장세 포에 부착하는 것을 방지하는 것이 최선책이라 할 수 있다. VTEC는 장관병원성대장균(enteropathogenic E. coli; EPEC)과 유사하게, 숙주세 포막의 부착(attachment)과 표적세포의 미세융모 소멸(effacement)을 특징으로 하는 'attaching and effacing(A/E) lesion'을 유발하는 것으로 알려져 있다(LeBlanc, 2003; Sherman 등, 1988). 이러한 부 착성은 eae(effacing and attaching E. coli) 유전자 산물에 의해 조절되고(Yu와 Kaper, 1992), 그 산 물은 intimin이라 명명된 $94 \mathrm{kDa}$ 의 세포외막단백질 (outer membrane protein; OMP)로 알려져 있다 (Sherman 등, 1991;Louie 등, 1993). 그리고 Mckee 와 O'Brien(1996)은 intimin에 대한 항혈청이 HEp-2세포에 대한 EHEC O157:H7의 부착성을 차 단한다고 보고하였다. 또한 intimin의 아미노산 서열 중에서 중앙이나 $\mathrm{N}$-말단 위치보다 C-말단의 아미노산 잔기가 HEp-2 세포와의 상호작용이 훨 씬 강하게 일어난다고 하였다(Kenny 등, 1997).

따라서, 본 연구에서는 intimin의 C-말단 부위 의 유전자를 cloning하고 재조합하여 in vitro 발 현 벡터를 구축한 다음, 발현된 재조합 단백질을
면역원으로 이용하여 토끼 및 산란계에 면역하여 O157:H7균에 대한 효율적 항체 생산 기법을 정 립하고자 실시하였다. 또한, 생산된 난황항체의 O157:H7균의 세포외막단백질 항원에 대한 결합 능력을 검증함으로서 영 - 아는 물론 성인에서 O157:H7균 감염에 의한 설사증의 예방 및 치료 항체로의 활용가능성을 타진하고자 실시하였다.

\section{재료 및 방법}

\section{1. 공시균주 및 배양}

장관출혈성대장균(Enterohemorrhagic Escherichia coli; EHEC) O157:H7 표준균주는 'EHEC O157: H7 EDL932’이며 American Type Culture Collection(ATCC, USA)에서 분양받았다. 균주 배양은 Zepeda-Lopez와 Gonzalez-Lugo(1995)의 방법에 따 라 Penassay broth에서 이루어졌으며, 균체는 $37^{\circ} \mathrm{C}$ 24 시간 배양한 배양액을 원심분리 $\left(5,000 \mathrm{~g}, 4^{\circ} \mathrm{C} \quad 20\right.$ 분)하여 회수한 다음 각 실험에 사용하였다.

\section{Intimin 유전자 클로닝 및 in vitro 발현 벡터 구축}

EHEC O157:H7 EDL932 균주로부터 genomic DNA의 분리는 Sambrook과 Russell(2001)의 phenol-chloroform 추출법에 따라 수행하였다. Intimin 단백질의 C-말단 281개의 아미노산을 지정하는 유전자를 클로닝하기 위하여, 추출된 genomic DNA를 주형으로 하여 sense-primer; GTCGGATCCTGATCAAACCAAGGCCAGCATT $\mathrm{AC}\left(\mathrm{BamHI}\right.$ site $5^{\prime}$ 에 포함)와 anti-sense primer; GTCGGTACCTTATTCTACACAAACCGCATAG( $K p n I$ site $3^{\prime}$ 에 포함)를 사용하여 PCR을 수행하 였으며, 그 조건은 다음과 같다; $95^{\circ} \mathrm{C}$ 3분; 1 cycle당 $95^{\circ} \mathrm{C} 1$ 분, $58^{\circ} \mathrm{C} 1$ 분, $72^{\circ} \mathrm{C}$ 2분, 총 30 cycles; $72^{\circ} \mathrm{C} \quad .0$ 분. PCR 산물을 $1.2 \%$ agarose gel 전기영동으로 확인한 다음 pCR2.1(Invitrogen Co.) 벡터에 삽입하여 competent 세포인 TOP10F' 에 형질전환을 시킨 후 양성클론을 선택하여 plasmid를 분리하였다. 분리된 plasmid를 제한 효 소 $\mathrm{BamHI}$ 과 $\mathrm{KpnI}$ (Promega Co.)으로 절단하여 얻 어진 $846 \mathrm{bp}$ 의 DNA 단편을, 동일한 제한효소로 
절단하여 준비한 발현 벡터 pQE-30(QIAgen Co.) 과 ligaton 반응을 실시하였다. 이를 competent 세포 M15[pREP4]에 형질전환시켜 양성클론을 선택하여 발현 벡터를 구축하였다(Fig. 1a).

\section{3. 재조합 intimin 단백질의 in vitro 발현 및 정제}

재조합 단백질인(His)6-tagged intimin C-말단 단백질의 생산 및 정제는 QIAgen Co.에서 제공 되는 protocol에 따라 진행하였으며, 그 과정을 간 단히 서술하면 다음과 같다. 양성클론을 $100 \mathrm{~m} \ell$ 의 $\mathrm{LB}$ broth에 진탕배양하여 흡광도 $\left(\mathrm{A}_{600}\right) \quad 0.6$ 에서

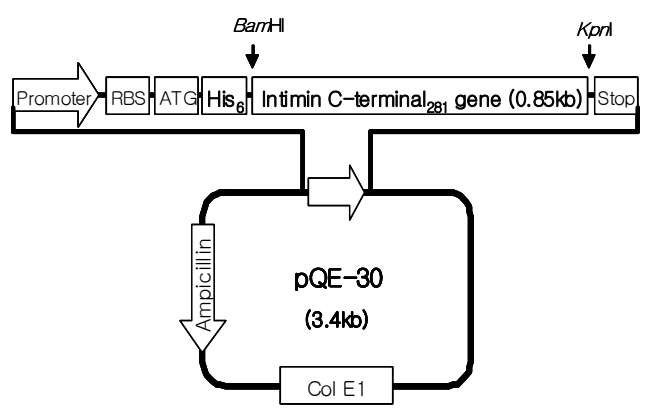

(a)

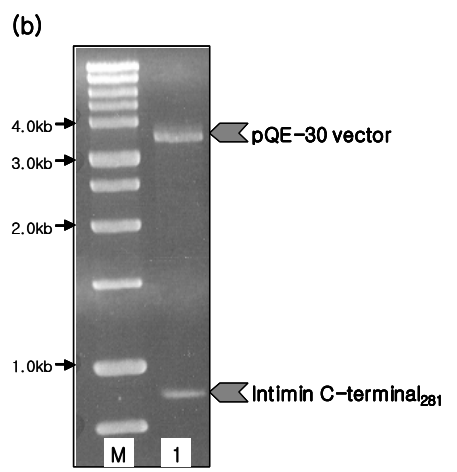

(b)

Fig. 1. Construction of intimin-expression pQE30 vector.

(a) Scheme of the recombinant vector. Intimin C-terminal 281 gene(846bp) is coding 281 amino acids of intimin Cterminal. RBS; ribosome binding site, Col E1; origin, Stop; stop codon. (b) Profile of the recombinant vector. In the Lane 1 , two fragments were separated by digestion of the recombinant by BamHI \& KpnI. M; 1kb DNA ladder marker.
$0.5 \mathrm{mM}$ 의 isopropyl- $\beta$-D-thio-galactopyranoside(IPTG; Sigma Co.)를 첨가하여 4시간 동안 intimin 발 현을 유도하고 원심분리(5,000g, 20분)하여 균주 를 회수한 다음, 용해완충액( $100 \mathrm{mM} \mathrm{NaH}_{2} \mathrm{PO}_{4}$, 10mM Tris-HCl, 8M urea[pH 8.0]; Sigma Co.)으 로 재부유시킨 후 30 분간 실온에서 진탕하였다. 완전히 용해된 세균을 $10,000 \mathrm{~g}, 20$ 분간 원심분리 하여 상청액 $4 \mathrm{~m} \ell$ 과 Ni-NTA resin(QIAgen Co.) $1 \mathrm{~m} \ell$ 를 상온에서 중탕 혼합하여 준비된 column 에 충진하였다. 세척완충액 $\left(100 \mathrm{mM} \mathrm{NaH} \mathrm{PO}_{4}\right.$, $10 \mathrm{mM}$ Tris- $\mathrm{HCl}, 8 \mathrm{M}$ urea[pH 6.3])과 용출완충액 (100mM NaH $\mathrm{PO}_{4}, 10 \mathrm{mM}$ Tris-HCl, 8M urea[pH 5.9])으로 resin을 세척 및 용출하여 분광광도계를 이용하여 흡광도 $\left(\mathrm{A}_{280}\right)$ 로 확인하였다. 분획된 단백 질을 $6 \mathrm{M}, 4 \mathrm{M}, 2 \mathrm{M}$ urea 완충액 $\left(100 \mathrm{mM} \mathrm{NaH}_{2} \mathrm{PO}_{4}\right.$, $10 \mathrm{mM}$ Tris- $\mathrm{HCl}[\mathrm{pH}$ 8.0])에서 단계적으로 투석한 후 BCA kit(Pierce Co.)를 이용하여 단백질 농도를 결정한 다음, 이 재조합 intimin 단백질인(His)6tagged intimin C-말단 단백질을 면역원성 실험 및 난황항체 생산의 항원으로 사용하였다.

\section{4. 재조합 Intimin 단백질에 대한 항체 생산}

(1) 공시동물 및 면역방법

항체 생산에는 22주령의 ISA-brown계통 산란 계 10 마리와 체중 $2.5 \mathrm{~kg}$ 의 New Zealand white종 토끼 2마리를 사용하였다. 사육은 단국대학교 동물자원학과 실험동물사육동에서 수행하였다.

재조합 단백질인(His) ${ }_{6}$-tagged intimin C-말단 단백질과 Freund's complete adjuvant(Gibco, USA) 를 동량으로 혼합하여 유화시켜 면역원으로 사 용하였으며 산란계에의 면역방법은 김 등(2000) 의 방법에 따라 실시하였고, 토끼에의 면역은 신과 김(2002)에 준하여 수행하였다.

\section{(2) 항혈청 및 난황항체 생산}

혈액은, 산란계는 날개밑정맥, 토끼는 귀정맥에 서 각각 2 주 간격으로 채취하였으며 $4^{\circ} \mathrm{C}$ 서 하룻 밤 보관후 원심분리하여 혈청중 항체역가 측정에 사용하였다. 또한 각각의 항혈청을 $-20^{\circ} \mathrm{C}$ 보관하 였다.

계란은 난황항체 역가가 일정수준 $\left(\geq 1^{5}\right)$ 에 도달한 이후 매일 회수하여 $8^{\circ} \mathrm{C}$ 저장하였다 
가 실험에 사용하였다. 우선, 난황을 분리한 후, 김 등(2000)의 방법에 따라 water soluble fraction(WSF)을 분리하고 난황항체를 정량한 다음, $-20^{\circ} \mathrm{C}$ 보관하였다.

\section{Western blot}

재조합 intimin 단백질에 대한 항혈청의 O157:H7 에 대한 결합능력을 조사하기 위하여, 앞서 토끼 에서 생산된 항혈청과 O157:H7균의 세포외막단 백질분획을 이용하여 western blot을 실시하였다.

O157:H7균의 세포외막단백질(OMPs) 분획 은 Achtman 등(1983)의 방법에 준하여 수행하 였고 약술하면 다음과 같다. Pennasay broth에서 하룻밤 배양된 균체를 용해완충액( $50 \mathrm{mM}$ Tris [pH 7.5], 50mM NaCl, 1mM phenymethylsulfonyl fluoride)으로 재부유 시킨 후 세포를 파쇄하였 다. 파쇄가 되지 않은 세균을 제거하기 위해 저속에서 원침하였다. 상청액을 다시 원심분리 (20,000g, 60분)하여 침전물을 멸균증류수로 녹인 후 $11.1 \mathrm{mM}$ Tris(pH 7.6)에 1.7\% N-lauroylsarcosine (Sigma Chemical Co.)가 함유한 용액을 1:8의 부피 비율로 가하여 실온에서 30 분간 진탕하였 다. 다시 원심분리를 하여 침전물을 sample buff$\mathrm{er}$ 에 녹여 SDS-PAGE의 시료로 사용하였다.

SDS-PAGE에 실시하여 분획된 OMPs에 대하여 Towbin 등(1979)의 방법에 따라 western blot을 실 시하였다. 분획된 OMPs를 nitrocellulose paper에 흡 착시킨 후 5\%의 탈지유완충액(Carnation Co.)으로 1.5 시간 동안 실온에서 방치하였다. 위에서 기술 한 토끼 항혈청을 1:100으로 희석하여 1차 항체로 사용하여 1.5 시간 반응시키고, 2 차 항체로는 alkaline phosphatase-conjugated goat anti-rabbit immunoglobulin(Jackson Co.)을 1:2,000으로 희석하 여 1 차 항체와 동일한 조건으로 반응시켰다. BCIP(5-bromo-4chloro-indolyl phosphate; Sigma Co.) 와 $\operatorname{NBT}(\rho$-nitro blue tetrazolium chloride; Sigma Co.) 을 사용하여 membrane을 가시화 하였으며 희석용 액으로는 TSB-T(Tris-buffered saline-0.05\% Tween20) 를 사용하였고 모든 세척은 3회 실시하였다.

\section{6. 면역반응}

재조합 intimin 단백질에 대한 산란계에서의
면역반응을 관찰하기 위하여, 정제된 재조합 intimin 단백질과 항혈청 또는 WSF의 결합반응 을 ELISA 방법으로 관찰하였다. 우선, 재조합 intimin 단백질을 $5 \mu \mathrm{g} / \mathrm{m} \ell$ 이 되도록 carbonatebicarbonate buffer(pH 9.6)로 희석하여 microplate (MicrotestIII flexble Assay plate; Falcon Co.)에

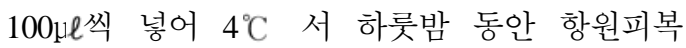
하였다. 피복이 완료된 plate를 세척용액 $(0.02 \mathrm{M}$ phosphate buffer, 0.13M NaCl[pH 7.2] containing $0.05 \%$ Tween20)으로 3회 세척한 후 5\% 탈지유용액(pH 7.3)(Difco Co.)을 각 well에 175 $\mu \ell$ 씩 분주한 후 2 시간 동안 실온에서 방치하 였다. $5 \%$ 탈지유용액과 세척용액을 동량으로 섞은 희석용액을 이용하여 WSF과 항혈청을 2,000 배 희석하여 3 배씩 단계적으로 희석하여 $37^{\circ} \mathrm{C}$ 서 2시간 반응시켰다. 2차 항체로는 AP-rabbit anti-chicken IgG 혹은 AP-donkey anti-rabbit IgG(Jackson Co.)를 5,000배로 희석하 여 $37^{\circ} \mathrm{C}$ 서 2시간 반응 시켰다. 기질용액으로 Phosphate substrate tablets( $\rho$-nitrophenyl phosphate; Sigma, USA)을 $10 \%$ diethanolamine(containing $0.5 \mathrm{mM} \mathrm{MgCl} 2, \mathrm{pH}$ 9.8)에 녹인 용액을 사용하여 15 분간 반응시키고 반응억제제로는 $5 \mathrm{M} \mathrm{NaOH}$ 를 사용하여 ELISA reader(EL800; Bio- Tec Co.)로 $405 \mathrm{~nm}$ 에서 흡광도를 측정하였다. 그리고 각 과 정 중 plate 세척은 7회씩 실시하였다.

\section{7. 중화반응시험}

재조합 intimin에 대한 난황항체의 EHEC O157:H7에 대한 방어효과를 알아보기 위하여 시험관내 중화반응시험을 수행하였다. 간략히 서술하면, $1 \times 10^{9}(\mathrm{CFU} / \mathrm{m} \ell)$ 농도로 희석된 $\mathrm{EHEC}$ O157:H7의 균체용액 $10 \mathrm{~m} \ell$ 을 멸균된 시험관에 분주한 후, $\operatorname{IgY}$ 농도가 각각 $5,10,15,20 \mathrm{mg}$ 이 되도록 $\mathrm{WSF}$ 를 첨가하였고, $\mathrm{IgY}$ 를 첨가하 지 않은 군을 대조군으로 하였다. $37^{\circ} \mathrm{C}$ 서 2 시간 진탕배양한 다음, 각각 $1 \mathrm{~m} \ell$ 씩 채취하여 $60^{\circ} \mathrm{C}$ 서 20 분간 열처리 후 냉장보관하여 실 험에 이용하였다. 반응정도 조사는 $\mathrm{Kim}$ 등 (1999)의 competitive sandwich ELISA 방법에 준하여 수행하였다. 2차 항체로는 자체 제작 한 rabbit anti-intimin antibody(1:2,000)와 AP- 
Donkey anti- rabbit IgG(1:1,250)를 혼합한 용액을 사용하였으며 완충액 및 세척방법은 항체 역가 측정방법과 동일하게 사용하였다.

III 결 과

\section{Intimin 재조합 발현벡터 구축}

Intimin의 C-말단부위를 표적 염기서열로 하 여 PCR을 수행한 결과 $846 \mathrm{bp}$ 의 PCR 산물을 얻었다. 이를 pCR2.1 벡터에 삽입하여 염기서 열 분석을 통하여 intimin 유전자를 확인하였 고 다시금 삽입된 벡터를 제한효소 $(\mathrm{BamHI}$, $K p n I)$ 로 처리하여 in vitro 발현 벡터인 pQE-30 과 ligation 반응을 실시하여 획득된 양성 클론 에 대한 제한효소 절단을 통한 검증결과, $3.4 \mathrm{~kb}$ 의 pQE-30 벡터와 846bp의 intimin C-말단 부 분으로 확인되었으며(Fig. 1b), 또한 염기서열 분석을 통하여 발현벡터 구축을 최종적으로 확인하였다.

\section{2. 재조합 intimin 단백질의 발현 및 정제}

Intimin의 C-말단 부위의 281개 아미노산과 6 개의 Histidine이 연결되어 발현되도록 구축한 재조합 pQE-30 벡터를 M15[pREP4] 세포에 형질전환을 실시하고 형질전환된 세균을 배 양하여 재조합 intimin 단백질의 발현을 SDSPAGE로 확인하였다(Fig. 2). IPTG의 발현유도

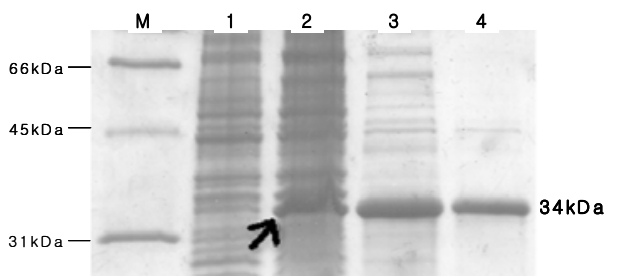

Fig. 2. Expression and identification of(His) ${ }_{6}{ }^{-}$ tagged intimin $\mathrm{C}$-terminal 281 protein. SDS-PAGE gel showing un-induced, IPTGinduced cellular proteins, cell lysates and the purified(His) ${ }_{6}$-tagged intimin protein (lane 1, 2, 3 and 4, respectively). The arrow indicate the induced(His) 6 -tagged intimin protein in cellular proteins. Lane $\mathrm{M}$ contained molecular size marker.
전후를 비교하여 약 $34 \mathrm{kDa}$ 정도에서목적 단 백질인 재조합 intimin 단백질이 발현되었다 (Fig. 2, Lane 2). 또한 배양된 세균을 용균시킨 후 Ni- NTA column을 이용하여 분리 및 정제하 였고(Fig. 2, Lane 4), 이것을 항혈청 및 난황항 체 생산을 위한 면역원으로 사용하였다.

\section{3. 재조합 intimin 단백질에 대한 항혈청과 O157:H7 OMPs 분획과의 결합반응}

토끼에서 생산된(His)6-tagged intimin C-말단 단백질에 대한 항혈청을 일차항체로 사용하여 O157:H7 OMPs 분획을 검출할 수 있는지에 대한 western blot을 실시한 결과, $94 \mathrm{kDa}$ 의 $\mathrm{O} 157: \mathrm{H} 7$ OMPs 분획과 항혈청이 결합하여 nitrocellulose membrane상에서 양성반응을 나타내었다(Fig. 3).

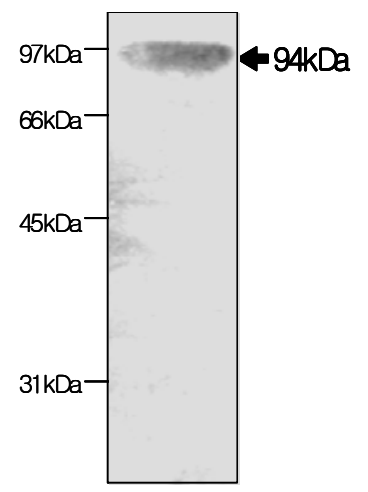

Fig. 3. Western blot analysis of OMPs extracted from EHEC O157:H7.

After SDS-PAGE, the OMP proteins were transferred to nitrocellulose and probed with(His) 6 -tagged intimin C-terminal 281 protein. (His) ${ }_{6}$-tagged intimin C-terminal 281 protein fused with sizes of approximately $94 \mathrm{kDa}$ of OMPs indicated by the arrow.

\section{4. 재조합 intimin 단백질에 대한 면역반응}

재조합 intimin 단백질을 면역원으로 산란계 면역시킨 후 난황항체와 항혈청의 주별 면역반 응을 관찰한 결과, 면역 후 2주 경부터 재조합 intimin에 대한 항체가 형성되기 시작하여 5주 경부터는 서서히 증가하여 8주경 이후 최고의 항체가를 유지하였다(Table 1). 
Table 1. Antibody titer of hens immunized with (His)6-tagged intimin C-terminal 281 protein

\begin{tabular}{|c|c|c|c|}
\hline \multirow{2}{*}{$\begin{array}{l}\text { Weeks after } \\
\text { immunization }\end{array}$} & \multirow{2}{*}{$\begin{array}{c}\text { No. } \\
\text { of hens }\end{array}$} & \multicolumn{2}{|c|}{$\begin{array}{c}\text { Antibody titer } \\
\text { (geometric mean titre } \\
\pm \mathrm{SD})^{\dagger}\end{array}$} \\
\hline & & $\begin{array}{c}\text { Egg-yolk } \\
\text { IgY }\end{array}$ & $\begin{array}{c}\text { Serum } \\
\text { IgG }\end{array}$ \\
\hline 0 & 10 & $1.95 \pm 0.1$ & $2.30 \pm 0.5$ \\
\hline 2 & 10 & $4.07 \pm 1.0$ & $4.47 \pm 1.2$ \\
\hline 5 & 9 & $5.07 \pm 0.7$ & $5.17 \pm 1.5$ \\
\hline 8 & 9 & $5.30 \pm 1.3$ & $5.25 \pm 0.6$ \\
\hline 11 & 9 & $5.36 \pm 0.8$ & $5.30 \pm 1.7$ \\
\hline 15 & 9 & $5.34 \pm 0.8$ & $5.32 \pm 0.9$ \\
\hline
\end{tabular}

$\dagger$ eometric mean titres are expressed as natural $\log$ transformed values.

\section{EHEC O157:H7에 대한 중화반응시험}

재조합 intimin 단백질에 대한 난황항체의 O157:H7에 대한 방어효과를 알아보기 위하여 중 화반응시험을 수행한 결과, 난황항체를 $\mathrm{m} \ell$ 당 5 $20 \mathrm{mg}$ 첨가 시, 균의 농도가 $10^{9} \mathrm{CFU} / \mathrm{m} \ell$ 에서 $10^{6} \mathrm{CFU} / \mathrm{m} \ell$ 로 약 1,000 배 감소하였다. 그러나, 난황 항체의 첨가농도 증가에 따른 $\mathrm{O} 157: \mathrm{H7}$ 균 농도의 유의적 감소는 보이지 않았다(p>0.05)(Table 2).

Table 2. The changes of EHEC O157:H7 concentration according to different treatment levels of $\lg Y$

\begin{tabular}{cc}
\hline IgY Treatment(mg) & $\begin{array}{c}\text { Bacteria(CFU/m } \ell) \\
\text { After 2 hours }\end{array}$ \\
\hline \hline Control & $1.9 \times 10^{9}$ \\
5 & $3.3 \times 10^{6}$ \\
10 & $3.4 \times 10^{6}$ \\
15 & $3.5 \times 10^{6}$ \\
20 & $3.7 \times 10^{6}$ \\
\hline
\end{tabular}

\section{$\mathrm{IV}$ 고 찰}

본 연구에서는 EHEC 0157:H7의 intimin 유전 자 중 C-말단 아미노산 281개에 해당하는 유전자 를 클로닝하여 in vitro 발현 벡터를 구축하고 재 조합 intimin 단백질을 발현시켜 산란계와 토끼에 면역하여 항혈청을 제조하였으며 이 항혈청은 EHEC O157:H7의 OMP와의 western blot을 수행
한 결과 양성반응을 나타내었다(Fig. 2b). 또한 생 산된 난황 항체를 이용하여 EHEC O157:H7에 대 한 중화반응시험을 통하여 난황 항체가 $\mathrm{O} 157: \mathrm{H7}$ 을 중화한다는 것을 확인하였다(Table 3).

Intimin의 C-말단부위의 약 281개의 아미노산 을 발현시키기 위해 PCR을 이용하여 $846 \mathrm{bp}$ 의 크기의 DNA 단편을 검출하였다. 검출된 $\mathrm{DNA}$ 단편을 insert로 하여 expression vector에 ligation 시켜 6개의 Histidine과 intimin의 281개의 C-말 단 아미노산이 혼합되어진 plasmid를 작성하였 다. Cloning된 숙주세포 M15[pREP4]에서 발현 되는 유전자 재조합 단백질을 분석하기 위하여 IPTG로 induction 전과 후의 균주의 protein profile을 SDS-PAGE로 비교하였을 때 Fig. 3a에서 제시한 바와 같이 induction 전의 세균에서 관 찰되지 않은 단백분획이 발견되었으며 그 분자 량은 $34 \mathrm{kDa}$ 으로 나타났다. 한 개의 아미노산을 $110 \mathrm{Da}$ 으로 가정했을 때 281개 아미노산은 약 $31 \mathrm{kDa}$ 으로 환산이 되나 6 개의 Histidine $(0.88 \mathrm{kDa})$, 시작. 결 codon 사이에 존재하는 MCS(multi-cloning site), 그리고 전기영동 상에 서 Rf값(retardation factor value)을 측정하여 분 자량을 산출하는 데에서 발생되는 오차 등을 고 려하여 볼 때 $34 \mathrm{kDa}$ 이 적정한 크기라 추정된다.

Mckee 등(1996)은 intimin에 대한 항혈청이 HEp-2 세포에 대한 EHEC O157:H7의 부착성 을 차단한다고 보고하였고, Kenny 등(1997)은 intimin의 아미노산 서열 중에서 중앙이나 $\mathrm{N}$-말 단 위치보다 C-말단의 아미노산 잔기가 HEp-2 세포와의 상호작용이 훨씬 강하게 일어난다고 보고한 바와 같이, 본 연구에서도 intimin C-terminal 281개의 아미노산 잔기로 구성된 재 조합단백질을 토끼에 면역하여 제조한 항혈청 을 시료로 하여 western blot을 수행한 결과 EHEC O157:H7의 OMPs $(94 \mathrm{kDa})$ 와 강하게 결합 하는 것이 확인되었다(Fig. 3b). 따라서 본 연구 에서 제작한 재조합 intimin 단백질은 $\mathrm{EHEC}$ O157:H7의 OMPs에서의 항원 결정기를 포함하 고 있으며 동시에 EHEC O157:H7에 특이적 반 응이 가능한 항체라고 사료된다.

발현된 재조합 intimin 단백질의 항원성을 확 인한 후 이를 면역원으로 하여 산란계에 주사 하여 혈청과 난황에서 면역반응을 조사하였다. 
Table 1에서와 같이, 항체가는 면역 2주부터 서 서히 증가하여 6주 이후부터 난황 항체가의 수 준은 혈청 항체가와 유사한 현상을 보였다. Shimizu 등(1998)의 연구에서 혈액중에 형성된 항체가 몇 주 후에는 난황으로 이전된다고 보 고하였으며 본 연구에서도 면역 직후 혈중에 형성된 항체가 4 주경에 난황으로 점차 이전 되는 현상을 관찰할 수 있었다.

특이난황 항체(specific anti-intimin IgY)의 EHEC O157:H7에 대한 중화반응검사를 실시한 결과, 난황 항체 5 $) \mathrm{mg} / \mathrm{m} \ell$ 으로 $10^{9}(\mathrm{CFU} / \mathrm{m} \ell)$ 인 $\mathrm{O} 157$ : $\mathrm{H} 7$ 세균의 농도를 $10^{6}(\mathrm{CFU} / \mathrm{ml})$ 수준으로 중화 시키는 것으로 나타났다(Table 2). 이 결과는 대장균의 부착성 인자(adhesive antigen)에 대한 난황 항체의 inhibition test에서 세균 수가 감소 되었다는 김 등(1998)의 보고와 난황 항체에 대 한 임상반응(clinical response)에서 대장균에 감 염된 자돈의 경우, 일당 증체량과 분변지수(FC score) 등의 현저한 증 - ㅏㅅㅅ하였다는 Marquardt 등(1999)의 보고와 같이, 재조합 intimin에 대한 난황 항체가 EHEC O157:H7 수를 현격히 감소 시키는 효과가 있음을 시사한다. 한편, 본 실험 에서 난황 항체의 첨가량의 증가에 따른 $\mathrm{O} 157$ : $\mathrm{H} 7$ 수의 유의적 감소는 보이는 않았는데, 이러 한 현상은 본 연구에서 이용된 실험방법의 제 한성으로 인하여 그 원인을 정확히 규명할 수 는 없으나 중화반응에 이용된 $\mathrm{Kim}$ 등(1999)의 competitive sandwich ELISA 방법의 정확도와 민감도가 $10^{4-5} \mathrm{CFU} / \mathrm{m} \ell$ 이상의 농도에서만 유효 하기 때문에 나타난 현상으로 추정된다.

결론적으로, 발현된 재조합 intimin 단백질은 토끼와 산란계의 면역반응을 유도할 수 있는 효율적인 면역원임과 동시에 난황 항체 생산을 위한 항원으로의 이용가능성이 확인되었다. 또 한 난황 항체의 탁월한 중화 효과 및 난황 내 다량의 항체 함유와 난황 자체의 고영양성 등 을 고려해 볼 때에 사람에서 EHEC O157:H7에 의한 출혈성대장염의 예방 및 치료목적으로 활 용도가 높을 것으로 기대된다.

$$
\mathrm{V} \text { 요 약 }
$$

장출혈성대장균 $\mathrm{O} 157: \mathrm{H7}$ 의 eae유전자 산물인 intimin은 장 상피세포의 부착성을 조절하는 단 백질로 알려져 있다. Intimin의 C-말단 아미노 산 잔기와(His) ${ }_{6}$ 이 혼합되어 이루어진 plasmid를 작성하여 재조합 단백질 $(34 \mathrm{kDa})$ 을 발현시켰다. 발현된 재조합 intimin 단백질의 면역원성을 확 인하기 위해 토끼와 산란계에서 항혈청 및 난 황항체(IgY)를 제조하였다.

O157:H7에서 분리한 세포외막단백질(OMPs) 과 제조된 항혈청과의 western blot상의 반응에 서 약 $94 \mathrm{kDa}$ 의 위치에서 양성반응을 보여 발현 된 재조합 단백질의 면역원성 효과가 확인되었 다. 면역원성이 확인된 단백질을 산란계에 면 역한 결과, 면역 후 4 주 경부터 높은 수준 의 항체가 형성되었다.

재조합 intimin 단백질에 대한 난황 항체의 항 원결합능력 조사를 위하여 중화반응시험을 수행 한 결과, 재조합 intimin 단백질에 대한 난황 항체 가 $\mathrm{O} 157: \mathrm{H} 7$ 과 강하게 결합하는 것으로 나타났다.

따라서 본 연구에서 발현된 재조합 intimin 단 백질은 토끼와 산란계의 면역반응을 유도할 수 있는 효율적인 면역원임과 동시에 난황 항체 생 산을 위한 항원으로의 이용가능성이 확인되었다.

\section{$\mathrm{VI}$ 사 사}

이 연구는 2003학년도 단국대학교 대학연구 비의 지원으로 연구되었음.

\section{VII 인 용 문 헌}

1. Achtman, M., Mercer, A., Kuseck, B., Pohl, A., Heuzenroeder, M., Aaronson, W., Sutton, A. and Silver, R. P. 1983. Six widespread bacterial clones among Escherichia coli K1 isolates. Infect. immun. 39:315-335.

2. Endo, Y., Tsurugi, K., Yutsudo, T., Takeda, Y., Ogasawara, T. and Igarashi, K. 1988. Site of action of a vero toxin(VT2) from Escherichia coli O157:H7 and of shiga toxin on Eukayotic ribosome. Eur. J. Biochem. 171:45-50.

3. Gyles, C. L. and Thoen, C. O. 1993. Pathogenesis of bacterial infections in animals, 2nd edition., Iowa state university press, U.S.A. p. 172.

4. Karmaili, M. A. 1989. Infection by verocytotoxinproducing Escherichia coli. Clin. Microbiol. Rev. 2:15-38.

5. Kenny, B., DeVinney, R., Stein, M., Reinscheid, D. J., 
Frey, E. A. and Finay, B. B. 1997. Enteropathogenic E. coli(EPEC) transfers its receptor for intimate adherence into mammalian cell. Cell 91: 511-520.

6. Kim, J. W., Jin, L. Z., Cho, S. H. and Marquardt, R. R. 1999. Use of chicken egg-yolk antibodies against $\mathrm{K}^{+}{ }^{+}$fimbrial antigen for quantitative analysis of enterotoxigenic Escherichia coli(ETEC) $\mathrm{K}^{+}{ }^{+}$ by sandwich ELISA. J. Sci. Agic. 79:1513-1518.

7. Kim, Y. B., Okuda, J., Matsumoto, C., Morigaki, T., Asai, N., Watanabe, H. and Nishibuchi, M. 1998. Isolation of an Escherichia coli O157:H7 strain producing Shiga toxin 1 but not Shiga toxin 2 from a patient with hemolytic uremic syndrome in Korea. FEMS Microbiol. Lett. 166(1):43-48.

8. Kleanthous, H., Fry, N. K., Smith, H. R., Gross, R. J. and Rowe, B. 1988. The use of sorbitolMacConkey agar in conjunction with a specific antiserum for the detection of Vero cytotoxinproducing strains of Escherichia coli O157. Epidemiol. Infect. 101(2):327-335.

9. Konowalchuk, J., Dickie, N., Stavric, S. and Speirs, J. I. 1978. Properties of an Escherichia coli cytotoxin. Infect. Immun. 18:575-577.

10. Konowalchuk, J., Speirs, J. I. and Stavric, S. 1977. Vero response to a cytotoxin of Escherichia coli. Infect. Immun. 18:775-779.

11. LeBlanc, J. J. 2003. Implication of virulence factors in Escherichia coil O157:H7 pathogenesis. Crit. Rev. Microbiol. 29(4):277-296.

12. Louie, M., Azavedo, J. C. S., Handelsman, M. Y. C., Clark, C. G., Ally, B., Dytoc, M., Sherman, P. and Brunton, J. 1993. Expression and characterization of the EaeA gene product of Escherichia coli serotype O157:H7. Infect. Immun. 61:4085-4092.

13. Marquardt, R. R., Jin, L. Z., Kim J. W., Fang, L., Andrew, A. F. and Samuel K. B. 1999. Passive protective effect of egg-yolk antibodies against enterotoxigenic Escherichia coli $\mathrm{K}^{+} 8^{+}$infection in neonatal and early-weaned piglets. FEMS Immun. Med. Micro. 23:283-288.

14. Marques, L. R., Moore, M. A., Wells, J. G., Wachsmuth, I. K. and O'Brien, A. D. 1986. Production of Shiga-like toxin by Escherichia coli. J. Infect. Dis. 154(2):338-341.

15. McKee, M. L. and O'Brien, A. D. 1996. Truncated enterohemorrhagic Escherichia coli(EHEC) O157:H7 intimin(EaeA) fusion proteins promote adherence of EHEC strains to HEp-2 cells. Infec. Immun. 64:2225-2233.

16. O’Brien, A. D. and LaVeck, G. D. 1983. Purification and characterization of a shigella dysenteriae I ike toxin produced by Escherichia coli. Infect. Immun. 40:675-683.

17. O'Brien, A. D., Newland, J. W., Miller, S. F., Holmes, R. K., Smith, H. W. and Formal, S. B. 1984. Shiga-like toxin converting phages from
Escherichia coli strains that cause hemorrhagic colitis or infantile diarrhea. Science 226:694-696.

18. Sambrook, J. and Russell, D. 2001. Molecular Cloning: A laboratory manual, 3rd edition., Cold Spring Habor, Inc., New York, U.S.A.

19. Sargeant, J. M., Sanderson, M. W., Smith, R. A. and Griffin, D. D. 2003. Escherichia coli $\mathrm{O} 157$ in feedlot cattle feces and water in four major feedercattle states in the USA. Prev. Vet. Med. 61(2):127-135.

20. Sherman, P., Soni, R. and Yeger, H. 1988. Characterization of flagella purified from enterohemorrhagic, Vero-cytotoxin-producing Escherichia coli serotype O157:H7. J. Clin. Microbiol. 26:1367-1372.

21. Sherman. P., Cockerill, F., Soni, R. and Brunton, J. 1991. Outer membranes are competitive inhibitors of Escherichia coli O157:H7 adherence to epithelial cells. Infec. Immun. 59:890-899.

22. Shimizu, M., Frtzsimmons, R. C. and Nakai, S. 1998. Anti-E. coli immunoglobulin $\mathrm{Y}$ isolated from egg yolk of immunized chickens as a potential food ingredient. J. food Sci. 53:1360-1366.

23. Tesh, V. L. and O'Brien, A. D. 1992. Adherence and colonization mechanisms of enterophathogenic and enterohemorrhagic Escherichia coli Microb. Pathog. 12:245-254.

24. Towbin, H., Staehelin, T. and Gordon, J. 1979. Electrophoretic transfer of proteins from polyacrylamide gels to nitrocellulose sheets: procedure and some applications. Proc. Natl. Acad. Sci. U.S.A. 76:4350-4354.

25. Tzipori, S., Karch, H., Wachsmuth, K. I., RobinsBrowne, R. M., O'Brien, A. D., Lior, H., Cohen, M. L., Smithers, J. and Levine, M. M. 1987. Role of a 60-megadalton plasmid and Shiga-like toxins in the pathogenesis of infection caused by enterohemorrhagic Escherichia coli O157:H7 in gnotobiotic piglets. Infec. Immun. 55:3117-3125.

26. Yu, J. and Kaper, J. B. 1992. Cloning and characterization of the eae gene of enterohaemorhaggic Escherichia coli O157:H7. Mol. Microbiol. 6:411-417.

27. Zepeda-Lopez, H. M. and Gonzalez-Lugo, G. M. 1995. Escherichia coli adherence to HEp-2 cells with prefixed cells. J. Clin. Microbiol. 33(5):1414-1417.

28. 김정우, 김도균, 김철. 2000 . 장관독성 대장균 K99(F5)의 섬모항원에 대한 특이 난황항체의 생 산. 한국동물자원과학회지. 42:371-380.

29. 김철. 1998. 가축의 설사유발 장독성 대장균 K99 균주의 pili 분리와 특이난황 항체의 생산에 관한 연구. 석사학위논문.

30. 신순오, 김정우. 2002. 장독성대장균 F41 섬모항 원에 대한 특이난황 항체 생산. 한국동물자원과 학회지. 44(5):633-642.

31. 정석찬, 정병열, 조윤상, 김종염, 이재진. 1996. 병원성 대장균(O157:H7) 감염증의 특성 및 예방 대책. 대한수의사회지. 32:546-552.

(접수일자 : 2004. 1. 8. / 채택일자 : 2004. 4. 2.) 